\title{
レター
}

\section{フィナステリドとメラトニンにより発毛した 脱毛症 Xのトイ・プードルの 1 症例 \\ Hair Growth of a Toy Poodle with Alopecia X after Finasteride and Melatonin Therapy: A Case Study}

\author{
坂田雷太* \\ 坂田犬猫病院 \\ Raita Sakata* \\ Sakata Dog and Cat Hospital
}

Received October 4, 2012 and accepted March 14, 2013

脱毛症 Xは, 犬の稀な皮膚疾患で, 全身症状の 無い, 左右対称性, 非炎症性, 非掻痒性, 進行性 脱毛症である 2)。ほとんどの罹患犬は 9 カ月から 2 歳の間に発症 ${ }^{2)}$ し, ポメラニアン，サモエド， ミ ニチュア・プードル等の好発犬種の存在が明らか になっている5)。本症に対する特異的治療法は確 立していないが，去勢手術やトリロスタンに反応 するという報告もある ${ }^{3,5)}$ 。今回，メラトニンとフ イナステリドの併用により発毛が認められた脱毛 症 Xの症例を経験したので，その概要を報告する。

症例は, 避妊雌, 体重 $2.5 \mathrm{~kg}$ のトイ・プード ル。1歳 6 カ月頃より体幹部の脱毛が始まり, 症 状は徐々に悪化した。2011 年 9 月, 6 歳 7 力月齢 時に脱毛などの症状が悪化したため, 皮膚検査を 行った。皮疹として，側腹部および背部を中心と した体幹部における左右対称性の脱毛が認められ た（図 $1 \mathrm{~A}, \mathrm{~B})$ 。脱毛および鱗屑付着部の皮膚押捺 検査において球菌やマラセチアなどは認められず, 皮膚掻爬検査および抜毛検査によっても外部寄生 虫および真菌などは検出されなかった。また，毛 幹を顕微鏡下で観察したが，異常に凝集したメラ ニン顆粒は認められなかった。完全血球計算, 血 液生化学検査, 尿検査および皮膚糸状菌培養検査 においても，異常所見は認められなかった。内分 泌疾患などを鑑別することを目的として, 各種ホ

*連絡先：坂田雷太 (坂田犬猫病院)

干 838-0068 福岡県朝倉市甘木 1368-12

TEL 0946-23-0221 FAX 0946-23-0221

E-mail: raita0808@yahoo.co.jp
ルモン検査を行った。 T4, gT4, ACTH刺激後コ ルチゾール值, 成長ホルモン, エストラジオール, プロゲステロン，テストステロン，アンドロステ ンジオン， $17 \alpha$ ヒドロキシプロゲステロンおよび DHEA-S 值はすべて参照範囲内であった。また, 本症例は，季節に関係なく通年性の脱毛が認めら れたため，季節性側腹部脱毛症は除外した。2011 年 11 月，皮膚脱毛病変部位の皮膚パンチ生検を 行った。病理組織学的所見において，表皮はほほ 正常な厚さであったが，表層は過角化を示してい た。多くの毛包は萎縮し, 一部で軽度な外毛根鞘 角化を伴っていた。以上の所見より，本症例を脱 毛症 X と診断し, メラトニン (Melatonin, Vitamin World, NY, USA）を $1.2 \mathrm{mg} / \mathrm{kg}$ で 1 日 2 回の経口投 与を開始した。3 カ月間投与したが変化は認められ なかったため, フィナステリド（Propecia, Merck, Germany）を $0.1 \mathrm{mg} / \mathrm{kg}$ で 1 日 1 回の経口投与を併 用したところ, 併用してから 3 カ月経過した段階 で背部における被毛の発毛が認められた。その後 も順調に発毛し（図 2A，B），現在まで維持されて いる。フィナステリドにはヒトで肝障害等の副作 用が認められることがあるため，投与中は 1 カ月 毎に完全血球計算, 血液生化学検査および尿検査 を行ったが, いずれにおいても異常所見は認めら れず，本治療による有害事象は認められなかった。

脱毛症 Xの病因はいまだに不明であるが3,5)，そ

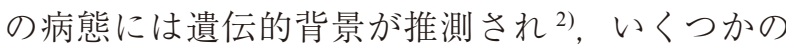
仮説が提唱されている。現在, 成長ホルモンの不 足 ${ }^{5)}$, 副腎における性ホルモン産生の異常 ${ }^{3,5)}$, 毛 

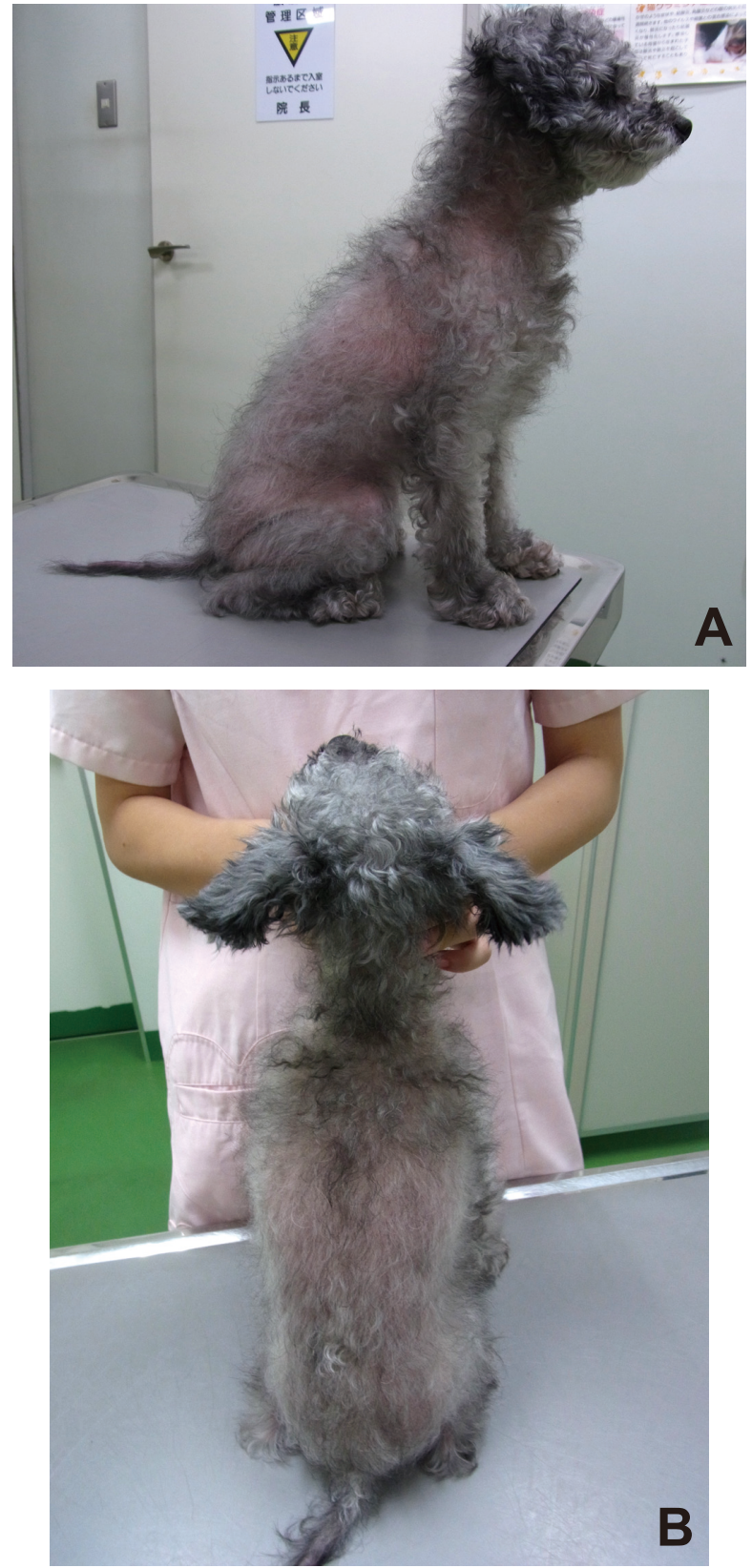

図 1 治療前の外観

側腹部（A）および背部（B）を中心に体幹部の左右 対称性脱毛が認められる.
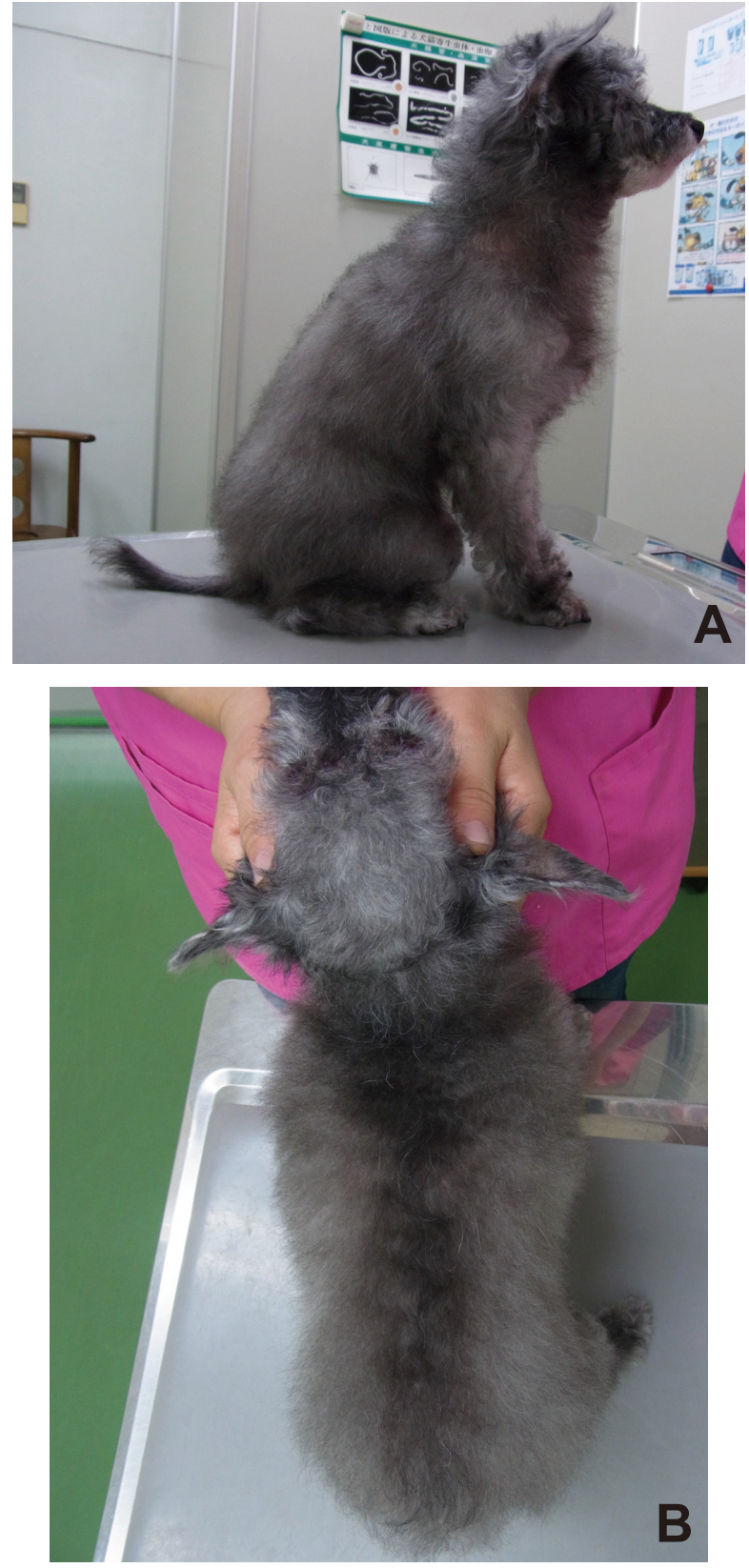

図 2 フィナステリド併用 6 カ月後の外観 治療前と比較し側腹部（A）および背部（B）を中心 に体幹部の発毛が認められる。
包に限局したホルモンレセプター代謝異常 $2,3,5)$ な どが示唆されている。本症例においては, 成長小 ルモンおよび各種性ホルモン值が参照範囲内であ ったことから，毛乳頭細胞レセプターにおける性 ホルモン代謝を改善させること ${ }^{6)}$ を期待してフィ ナステリドを併用した。松果体ホルモンであるメ ラトニンは, 副作用が少なく, 毛包レセプターに おける性ホルモン代謝に影響を及ぼす可能性があ る ${ }^{3)}$ 。一方， 2 型 $5 \alpha$ リダクターゼ阻害薬であるフ
イナステリドは 6), 毛乳頭細胞男性ホルモンレセ プターにおいて，テストステロンからジヒドロテ ストステロンへの変換を阻害することにより発毛 効果を発現する ${ }^{4)}$ 。本来, 男性ホルモン性脱毛症 に対する治療薬として認可されているが，ヒト女 性の男性ホルモン性脱毛症に打いても発毛効果が あるという報告もある1)。このことから，メラト ニンにフィナステリドを併用したことが, 雌であ る本症例においても, 毛周期が休止期で停止して 
いた毛包の毛乳頭細胞男性ホルモンレセプターに おいて，テストステロンからジヒドロテストステ ロンへの変換を阻害することにより, 毛周期が再 び成長期に入り，発毛効果を発現したのではない かと推測された。脱毛症 Xは，審美的問題に過ぎ ないとも言われるが，オーナーの強い要望があり， 成長ホルモンおよび各種性ホルモンに異常がなけ れば，本治療も選択肢に入ると思われた。

\section{謝 辞}

本症例の病理組織診断を行っていただいた帝京 科学大学の関口麻衣子先生に感謝いたします。

\section{引用文献}

1) Boychenko, O., Bernstein, R.M. and Schweiger, E.S. 2012. Cutis. 90: 73-76.

2) Gross, T.L., Ihrke, P.J., Walder, E.J. and Affolter, V.K. 2009. pp. 497-500. 犬と猫の皮膚病（第 2 版）臨床および病理組織学的診断法, インター ズー, 東京.

3) Guaguere, E. and Prelaud, P. 2008. pp. 330-334. PRACTICAL GUIDE 犬の皮虐科学 (下巻), メ リアル・ジャパン, 東京.

4) Kamolpatana, K., Johnston, S.D., Hardy, S.K. and Castner, S. 1998. Am. J. Vet. Res. 59: 762-764.

5) Medleau, L. and Hnilica, K.A. 2006. pp. 249-251. カラーアトラス犬と猫の皮膚疾患, 2 nd ed., 文 永堂出版, 東京.

6) Whiting, D.A. 2001. Eur. J. Dermatol. 11:332334. 